\title{
ALLOCATION OF SECURITIES IN CORPORATE REORGANIZATIONS: CLAIMS MEASUREMENT THROUGH INVESTMENT VALUE ANALYSIS
}

Beginning with Los Angeles Lumber in 1939, the Supreme Court in a series of reorganization cases ${ }^{1}$ has brought the Boyd ${ }^{2}$ doctrine to full flower. As developed by the Court, Boyd now commands three basic canons: (1) The capitalization of the reorganized enterprise, as in any newly formed corporation, must be limited to the reasonable value of its assets, usually determined by capitalizing its future earnings. ${ }^{3}$ In a reorganization context, this limitation restrains over-optimistic reliance on debt financing, with its danger of future default. (2) The new security structure must be "feasible": the future burden of fixed charges, the schedule of debt maturities, and other features of the capital framework must be geared to expected income fluctuations in order to minimize the risk of default. ${ }^{4}$ Moreover, voting control must be based on substantial equity holdings. ${ }^{5}$ And in the case of utilities, the

1. (1) Case v. Los Angeles Lumber Products Co., 308 U.S. 106, 116-17 (1939); noted, e.g., 49 Y YLE L. J. 1099 (1940.). An extended discussion appears in Dodd, The Los Angeles Lamber Products Case and Its Implications, 53 HARv. L. Rev. 713 (1940). (2) Consolidated Rock Products Co. v. Dubois, 312 U.S. 510, 520-1 (1941), discussed in Comment, Distribution of Securities In Corporate Reorganization, 51 Yale L. J. 85 (1941). (3) Group of Institutional Investors v. Chicago, Milwaukee, St. Paul \& Pacific Railroad Co., 318 U.S. 523, 542 (1943) and Ecker v. Western Pacific Railroad Corp., 318 U.S. 448, 515 (1943). These cases, decided the same day, are analyzed in Swaine, $A$ Decadc of Railroad Reorganization Under Section 77 Of The Bankruptcy Act, 56 Hakv. L. Rev. 1037-58; 1193-1224 (1943).

2. Northern Pacific Railway Co. v. Boyd, 228 U.S. 482 (1913). See dicta pages of cases cited in note 1 supra for repeated references to the Boyd rule. For pre-Los Angeles Lumber comment on Boyd, see Rostow \& Cutler, Compcting Systems of Corporalc Rrorganization: Chapters X and XI Of The Bankruptcy Act, 48 YALE L.J. 1334 (1939).

3. Consolidated Rock Products v. Dubois, 312 U.S. 510, 525-6 (1941); Ecker v. Western Pacific Railroad Corporation, 318 U.S. 448, 477, 483 (1943); Group of Institutional Investors v. Chicago, Milwaukee, St. Paul \& Pacific Railroad Co., 318 U.S. 523, 541 (1943). See Field, Valuation for the Purposes of Carporatc Reorganization, 16 Rocky Mft. L. Rev. 13 (1943); I Dewing, Financial. Policy of Corporations 296 (4th ed. 1946) ; I Bonbright, Valuation of Property 253-7 (1st ed. 1937). Cf. Ballantine, Corporations 798 (rev. ed. 1946). But cf. valuations based on market value for portiolio assets of investment companies. Central States Electric Corp. v. Austrian, 183 F.2d 879) (4th Cir. 1950), cert. denied, 340 U.S. 917 (1951).

4. Consolidated Rock Products Co. v. Dubois, 312 U.S. 510, 526, 530-1 (1941); Grotu! of Institutional Investors v. Chicago, Milwaukee, St. Paul, \& Pacific Railroatd Co, 318 U.S. 523, 544-5 (1943).

5. Ecker v. Western Pacific Railroad Corp., 318 U.S. 448, 481 (1943). Cf. "Excessive voting power in proportion to financial interest in the company and control with a dispro. portionately small investment are the very evils which the ... [Public Utility Holding Company Act] is designed to correct." Federal Water Service Corp., 8 S.E.C. 893 (1941). 
special public interest in their financial stability may justify diverting some future income from junior interests to capital improvement and betterment funds. ${ }^{6}(3)$ Given the size and structure of the new capitalization, new securities must be allocated among investors in the old enterprise in the order of their contractual priority.

But "absolute priority" does not demand that new capital structures preserve the form of old priorities. Instead, each class must be "fully" compensated for priorities which "feasibility" requires to be surrendered. . To allocate new securities, "the claim" of each class is measured by valuing its investment contract rights. This measurement must consider "the entire bundle of rights" provided in the investor's old contract, more recently, the contract's "investment value." Thus, only if all prior classes have received the full "equitable equivalent" of relinquished rights may junior security holders participate at all. ${ }^{3}$ Otherwise their claims are "worthless," and they must be eliminated from the plan. ${ }^{10}$

This Comment explores the criteria utilized in measuring investor claims to determine their participation in reorganizaton plans.

\section{Claims Measurement in Chapter $X$ Reorganizatrons}

Chapter $X$ (formerly $\$ 77 B$ ) of the Bankruptcy Act governs reorganizations of insolvent non-railroad corporations. ${ }^{11}$ This legislation defined new reorganization procedures to replace equity receiverships;" "fair and equit-

6. E.g. Group of Institutional Investors v. Chicago, Milwaukce, St. Paul \& Pacific Railroad Co., 318 U.S. 523, 566-8 (1943).

7. Consolidated Rock Products Co. v. Dubois, 312 U.S. 510, 528-31 (1941).

8. SEC v. Central-Illinois Securities Corp., 338 U.S. 96, 129 (1949); Niagara Hudson Power Corp. v. Leventritt, 340 U.S. 336, 341 (1951). These cases arose under $\S 11$ of the Public Utility Holding Company Act. However, in the latter case the Court said: "[W] find no lack of authority in analogous fields of reorganization for sustaining the general principle that a class of securities may go unrecognized in a reorganization when informed estimates of future earnings indicate that they have no investment value." [Citing Group of Institutional Investors v. Chicago, Milwaukee, St. Paul \& Pacific Railroad Co., 318 U.S. 523 (1943) ( $\$ 77$ ) and Consolidated Rock Products Co. v. Dubois, 312 U.S. 510 (1941) ( $\$ 77 \mathrm{~B})]$. Id. at 347-8.

9. Group of Institutional Investors v. Chicago, Mfilwaukee, St. Paul \& Pacific Railroad Co., 318 U.S. 523, 565 (1943).

10. Case v. Los Angeles Lumber Products Co., 308 U.S. 105, 123-3 (1939); Group of Institutional Investors v. Chicago, Mfilvaukee, St. Paul \& Pacific Railroad Co., 318 U.S. 523, 541-2 (1943).

11. \$77B: 48 Stat. 912 (1934): Chapter X: 52 Stat. 911 (1938), 11 U.S.C. $\$ 766$ (1946). Chapter 11 of the Bankruptcy Act is the "composition" section, available to small non-publicly held corporations. See SEC v. United States Realty Co., 309 U.S. 434 (1940). For a discussion of Chapter 11 procedures and the initial uncertainty about its coverage, see Rostow \& Cutler, supra note 2.

12. Id. at 1335 et scq. 
able," the statutory guide to securities allocation, was left undefined. In Case v. Los Angeles Lumber Products Co., however, the Supreme Court read "fair and equitable" as "words of art" with a "fixed meaning" developed in equity receiverships: "absolute priority."13

In Los Angeles Lumber, arising under § 77B, the debtor had initiated proceedings by filing a voluntary petition in 1936 . One bond and two stock classes were outstanding: (1) $6 \%$ when-earned first mortgage bonds (to mature in 1944) ; (2) class A common; (3) class B common. ${ }^{14}$ The proposed plan called for cancellation of the old debt securities and issuance of new $5 \%$ preferred and common-both of $\$ 1$ par and with voting rights. ${ }^{15}$ Aggregate par value of new stocks issued to old security holders equaled $\$ 830,000$ - the estimated value of the assets. ${ }^{16}$ Although bondholders' claim to principal and interest totaled $\$ 3,807,071.88$, the plan gave them preferred shares with an aggregate par of $\$ 641,375 .{ }^{17}$ Class A common received 188,625 shares of new common; Class B common was wiped out. 18 Thus, common was to receive $23 \%$ of the assets and voting power of the new company even though the debtor's total assets, as valued for purposes of the case, were less than one fourth the face amount of the bondholders' claim. The Court held that the plan, as a matter of law, did not pass the "fair and equitable" test ${ }^{\mathbf{1 0}}$ unless the value of the corporation's assets exceeded creditors' claims, stockholders

13. 308 U.S. 106,115 (1939).

14. The debtor was a holding company. Only one of six wholly owned subsidiarics, Los Angeles Shipbuilding \& Drydock Corporation, had assets of sizeable value. The debtor's mortgage bonds were issued in 1924 and had a first lien on both the fixed assets of this subsidiary and the capital stock of all the subsidiaries. Interest payments on the bonds had stopped on February 1, 1929. A voluntary reorganization in 1930 reduced the interest rate from $71 / 2 \%$ to $6 \%$ and made it contingent on earnings. The debtor's old stock was cancelled and new Class A and Class B common issued. Class A went to old shareholders who contributed $\$ 400,000$ for working capital. Thus, Class $A$ was given preference to $\$ 400,000$ and interest over Class B in case of liquidation. Class B stock went to bondholders in payment of unpaid interest charges. Id. at 109-10.

15. Preferred was to be non-cumulative. After receiving a $5 \%$ dividend, common would be entitled to a similar dividend. Then both classes would participate equally in the remaining dividends. Similarly, preferred was to have a liquidation preference (par). And after common received the same amount, both classes would participate equally in the remaining assets. Id. at 111 .

16. This amount "equals the going concern value of the assets of the enterprisc." Ibid. The sum consisted of $\$ 430,000$ in fixed assets and approximately $\$ 400,000$ in current assets. Id. at 109 . However, the Court did not indicate the method of valuing the fixed assets. Later decisions made capitalized future earnings the essential mensurc. See note 3 supra and text.

17. Each old bond would be exchanged for 250 preferred shares. $92.81 \%$ of the face amount of bonds assented to the plan. Mieanwhile, 170,000 preferred shares were reserved for sale to raise money for rehabilitating the shipyards. 308 U.S. at 111 .

18. No new contribution was required of Class A stockholders. Ibid.

19. Id. at 114 . 
-in the absence of a new contribution in money or money's worth-forfeited the right to participate. ${ }^{20}$

Thus the Los Angeles Lumber decision held that when the value of assets $(\$ 830,000)$ fell far below the face amount of debt claims $(\$ 3,807,071.88)$, no equity was left for shareholders. Because bondholders' face claims exceeded asset values the court had no reason to look beyond face amounts in measuring bond claims. And despite the bonds' 1944 maturity date, the Court considered them matured for measurement purposes.

The unanimous decision in Consolidated Rock Producls Co. $v$. Dubois 21 spelled out the Supreme Court's notion of "absolute priority." Consolidated Rock: Products Company (Consolidated) and its two wholly owned subsidiariesUnion Rock (Union) and Consumers Rock and Gravel (Consumers)sought reorganization under $\$ 77 \mathrm{~B} .{ }^{22}$ Four security classes were outstanding: (1) Union 6\% mortgage bonds; (2) Consumers 6\% mortgage bonds; (3) Consolidated no-par preferred; (4) Consolidated no-par common.3 The plan contemplated consolidating the three companies and replacing the old securities with $5 \%$ cumulative mortage income bonds, $5 \%$ preferred, common and stock warrants. ${ }^{24}$ It met $50 \%$ of both Union and Consumers bondholders"

20. The Court rejected shareholders' fnancial standing, community influence, and advantages of management continuity as contributions warranting participation. "Such items are illustrative of a host of intangibles which, if recognized as adequate consideration for issuance of stock to valueless junior interests, would serve as easy evasions of the principle of full ... priority." Id. at 122. The Court also rejected: (1) Shareholders' waiver of the right to control the property till 1944 (maturity date of bonds), id. at 127; (2) Shareholders' waiver of ability to litigate their claims, absent bankruptcy reorganization, id. at 131 ; (3) Probability that bondholders in event of foreclosure would receive substantially less than the appraised value of the assets, id. at 123 .

21. 312 U.S. 510 (1941).

22. Id. at 514 .

23. The face claim of publicly-held Union bonds totalled $\$ 2,280,555$ (principal $\$ 1, \$ 77,000$; accrued interest $\$ 403,555$ ). Union's property secured the issue. Face claim of publicly-held Consumers bonds equalled $\$ 1,358,715$ (principal $\$ 1,137,000$; accrued interest $\$ 221,715$ ). Consumers property secured this issue. Preferred's liquidation claim was $\$ 25$ per share plus accrued dividends. 285,947 preferred shares and 397,455 common shares were outstanding. Id. at $\mathbf{5 1 4 - 5}$.

24. Bonds and preferred were to be divided into two series, one for Consumers and the other for Union bondholders. The new bonds would mature in 20 years; interest would be cumulative. Each bond and preferred stock series was entitled to a sinling fund. After bond interest and sinking fund payments, dividends could be declared on preferred. However, dividends would be non-cumulative until retirement of the same bond series except to the extent that net income is available for dividends. After bond retirement, preferred would be fully cumulative.

Stock warrants were of two types: (1) Each preferred share was given a warrant for the purchase of new common at prices ranging from $\$ 2$ to $\$ 6$ per share-depending on when exercised; (2) Warrants given to old common (one warrant for each five shares of common) entitled the holder to purchase one new common share for \$1 within three months of issuance. Id. at 515-6.

Normally, preferred shareholders would elect 4 out of 9 directors and common the remainder. And old preferred would receive most of the new common, even if all 
principal claim with income bonds, the other half with preferred. Bondholders' claims to accrued interest were to be extinguished. Preferred would receive new common on a one for one basis; old common would be given stock warrants. Net income of the new company was to be divided into two equal parts, one to service the new securities issued to Consumers bondholders and the other to service those issued to Union bondholders. ${ }^{25}$

The Court held the plan not "fair and equitable." The plan failed to treat accrued bond interest on the same basis as the claim to principal; bondholders were to relinquish a $6 \%$ fixed-interest claim for a $5 \%$ contingent claim in inferior securities; and their maturities were partly extended and partly elimininated. Thus, bondholders were not fully compensated for their surrendered rights. Yet junior interests were participating in the reorganization. ${ }^{20}$ The Court acknowledged that when "feasibility" requires a conservative capital structure with a minimum of fixed-interest charges, all or part of seniors' claims may be satisfied with inferior grades of securities or even the same securities given juniors. But structural streamlining could not compel relinquisliment without compensation of any prior claim to earnings or assets; senior claimants must receive other rights or greater participation-their precise nature to vary with the facts of each case. ${ }^{2 \pi}$ But in each case new rights received were to equal in value the old claims surrendered.28

The plan was deemed unfair for another reason. While their principal and interest rates matched, Consumers and Union bonds were secured by different assets. ${ }^{20}$ The proposed plan gave the same new securities to both bond classes and divided net income equally to service them, although no valuation had been made of the underlying assets securing each class. ${ }^{30}$ The

warrants were exercised. But if certain interest delinquencies occurred, then the old bondholders (holding the new preferred) would be entitled to elect six directors. Id. at 516-7.

25. Ibid.

26. Id. at $527-8$.

27. Id. at $528-9$.

28. Id. at $529-30$.

29. Union bonds' aggregate face claim exceeded Consumers by over $\$ 1,000,000$. Scc note 23 supra. But Union bondholders claimed that Union's assets were "much greater in volume and in value than those of Consumers." Id. at 525.

30. "The District Court did not find specific values for the separate propertics of Consolidated, Union, or Consumers." Id. at 517. (emphasis added). However, on the basis of testimony of three witnesses, the average valuation (apparently based on physical factors) of Union's property was $\$ 2,202,733$ (Union face claim $\$ 2,280,555$ ) and Consumers' $\$ 1,151,033$ (Consumers face claim $\$ 1,358,715$ ). Ibid. Thus the District Court found "that the present fair value of the assets admittedly subject to the trust indenture of Union and Consumers was insufficient to pay the amount ... of the respective bond issues." Id. at 518. But the Supreme Court found this valuation procedure inadequate. Id. at 524-5. But see Ecker v. Western Pacific Railroad Corp., 318 U.S. 448 (1943). "There is nothing . . . in the Dubois case to indicate that dollar valuations of the prop- 
Court considered valuation of underlying assets essential for measuring the respective claims of Consumers and Union bondholders to test the plan's fairness. And earnings potential was to be the basis for valuing the underlying assets. If no individual earnings records were available, some formula must measure respective asset values. ${ }^{31}$

While Consolidated Rock Products indicates the type of analysis and compensation required to measure and fully satisfy bondholders' claims, the Supreme Court has not yet defined the appropriate measure of preferred stockholders' rights. However, the recent reorganization of Central States Electric Corporation, an investment company, typifies the reliance by lower Chapter X courts on preferreds' liquidation claims. ${ }^{32}$ Central States' original capital structure consisted of debentures, two classes of preferred shares and common stock. Although the company was insolvent in 1942 when it petitioned for reorganization, by 1950 market value of portfolio securities exceeded debenture claims. $^{33}$ And the Fourth Circuit agreed with the SEC and district court that market value was the appropriate method for valuing portfolio assets of investment companies. ${ }^{34}$ The plan replaced Central States and two holding company subsidiaries with one investment company. One class of common comprised the new capital structure. ${ }^{35}$ The plan allocated to (1) debenture holders new common with a market value roughly $5 \%$ above debentures' liquidation claim; (2) senior preferred shareholders new common

erty or claims are essential for recapitalization or the distributions of securities in reorganizations. The defect in Dubois was not the failure to find dollar values but the failure to find the worth of the security behind independent mortgages on distinct properties. ..." Id. at 482 .

31. 312 U.S. at 524-5.

32. Central States Electric Corp. v. Austrian, 183 F.2d 879 (4th Cir. 1950), cerl. denied, 340 U.S. 917 (1951). The case is critically discussed in Billyou, Priority Rights of Preferred and Common Shares in Bankriptcy Reorganization, 65 HARv. L. REv. 93 (1951). Cf. Petition of Portland Electric Power Co., 162 F.2d 618 (9th Cir.), ccrf. denied sub nom. Watson v. Portland Electric Pover Co., 332 U.S. 837 (1947) (Chapter X) ; In re Childs Co., 69 F. Supp. 856 (S.D. N.Y. 1946) (Chapter X); In re Deep Rock Oil Corp., 113 F.2d 266 (10th Cir.), cert. denied sub nom. Standard Gas \& Electric Co. v. Taylor, 311 U.S. 699 (1940) (\$77B). Central States is a "holding company with a rather inactive portfolio of securities." 183 F.2d at 881.

33. Assets shrank to $\$ 1,400,000$ in 1942 . They rose, by 1950 , to $\$ 38,000,000$ at which time debentures' total face claim vas $\$ 20,700,000$. Ibid.

34. Id. at SS4. This valuation method is contrary to the usual practice of apitalizing future earnings. See note 3 supra and text.

35. Id. at 882 . The new investment company was to be "open-ended," i.e. new common would be redeemable at the option of its holders. But since the plan barred redemption for an initial sixty-day period, debentures and senior preferred received $\mathbf{3} 5 \%$ $21 / 2 \%$ bonus respectively to compensate for the risk of market fuctuations in that period. $.7 d$. at 882,888 . And since both old classes were losing their priorities in the reorganized company by accepting common, the bonuses were thought necessary to compensate these securities quantitatizely for loss of their gualitatize priority. Id. at 888-9. 
with a market value approximately $2 \frac{1}{2} \%$ above preferreds' liquidation claim of par plus dividend arrearages; (3) junior preferred shareholders the residual interest. ${ }^{36}$ Common received nothing. ${ }^{37}$ The bonuses to debentures and senior preferreds were designed in part to compensate for loss of their priorities in the new all-common stock structure. ${ }^{38}$ The Fourth Circuit approved the plan; the Supreme Court denied certiorari. ${ }^{30}$

Claims measurement in Central States by preferreds' liquidation rights parallels Los Angeles Lumber's reliance on the face amount of the debt to measure bond claims. In both cases the courts treated these claims as fully matured, although the due date of the bonds' principal in Los Angeles Lumber was six years distant and "liquidation" was not, in fact, occurring in Central States. The Central States approach is apparently based on the view that bankruptcy reorganization is a substitute for liquidation, and therefore, liquidation claims are the principal criterion for measuring preferred shareholders' participation. ${ }^{40}$ In similar Chapter $\mathrm{X}$ cases, as well as Contral States, denials of certiorari have barred a square Supreme Court ruling on the point. ${ }^{41}$ Moreover, Central States' "bonuses" to debenture and seniorpreferred holders for surrender of income priorities harmonizes with Consolidated Rock Products' insistence on compensation for bondholders beyond the same face amount of inferior securities. This identical Chapter $\mathrm{X}$ treatment

36. Security holders' claims were, roughly, as follows:

Debentures (including accrued and unpaid interest) ............... \$20,700,000

Senior Preferred $(7 \%)$ (liquidation preference) $\ldots \ldots \ldots \ldots \ldots \ldots \ldots \ldots . \ldots \ldots \ldots \ldots \ldots, 15,800,000$

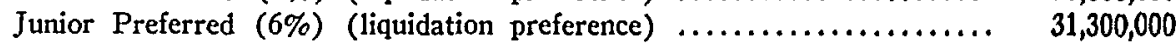

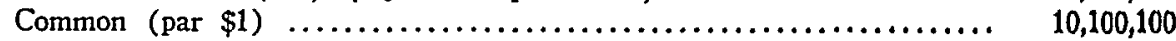

$I d$. at 881 . Since total assets were valued at $\$ 38,000,000$ and stock liquidation claims were held governing, junior preferred would receive the remainder and common nothing.

37. See note 36 supra.

38. See note 35 supra.

39. Central States Electric Corp. v. Austrian, 183 F.2d 879 (4th Cir. 1950), ccrt. denied, 340 U.S. 917 (1951).

40. " $[F]$ rom the standpoint of these stockholders, the old corporation is being virtt1ally dissolved and wound up and ... a new corporation is being created as a result of the reorganization. Consequently these preferred shareholders are entitled to the liquidation preference for which their stock provides." 183 F.2d at 885 . See also $I n$ rc Childs Co., SEC Corporate Reorg. Release No. 67, p. 44 (Sept. 30, 1946); Dodd, Preferred Shareholders Rights-The Engineers Public Service Company Case, 63 HAkv. L. REv. 298 (1949). "Reorganizations under the Bankruptcy Act are substitutes for liquidation, and there seems no reason to doubt that in such reorganizations liquidation preferences must be treated as matured, as bondholders' claims to principal must be under ... [Los Angeles Lumber]. . . "Id. at 305. For criticism of this view see Billyou, note 32 sibra.

41. See note 32 supra. 
stems, of course, from the initial equation of stock liquidation rights with bond face claims.

Consolidated Rock Products also prescribes a particular type of bond analysis that apparently goes well beyond reliance on face amount of debt to measure bondholder claims. In that case, the Supreme Court emphasized the necessity of valuing the assets which secured bonds with identical face claims. However, the Court did not articulate the full relevance of the divisional-value analysis. If the value of securing assets was below the face amount of bondholders' claims, the Court's insistence on the analysis may have extended only to determine the part of each class" liquidation claim that could be satisfied from its underlying assets. This would not involve a substantial departure from principal reliance on the face amount of the debt. On the other hand, if the value of the securing assets cxcceded bondholders' liquidation claims, ${ }^{42}$ the analysis takes on new significance: an allocation yardstick beyond face claims; to determine, for example, the comparative worth of each class' expectation of future interest payments. If that interpretation is correct, the Court must have meant that face amounts taken alone are incapable of measuring the relative value of competing claims, and that reorganizers, therefore, must examine the value of other rights in the investment contract as well. In fact, later $\$ 77$ cases, relying on Consolidatcd Rock Products, made divisional earning inquiries a prerequisite to allocation fairness. ${ }^{43}$

\section{InVESTAIEnt Value in $\$ 77$ Reorganizations}

Section 77 of the Bankruptcy Act, governing railroad reorganizations, also prescribes "fair and equitable" as the allocation standard." Depression years brought many of the country's debt-laden roads under $\$ 77.50$ ICC emphasis on "feasible" reorganization plans has required drastic structural changes, ${ }^{40}$ further complicating allocation problems. And the ICC, with judicial approval, has considered contract rights other than face and liquidation in measuring investors' claims to new securities.

42. For valuation data available see note 30 stpra.

43. See text on $\$ 77$ cases infra.

44. 47 Stat. 1474 (1933), as amended, 11 U.S.C. $\$ 205$ (1946). Analysis of procedures and standards in the 1933 statute is found in Dodd, Reorganization throngh Bont-ruptcy: A Remedy for What?, 48 HaRv. L. Rev. 1100 (1935). For historical discussion of standards of allocation fairness applied in railroad and other reorganizations, see Swaine, Reorganization of Corporations: Certain Derelopments of the Last Decade, 27 CoL. L. Rev. 901 (1927), 28 CoL L. Rev. 29 (1928) ; and Rodgers \& Groom, Rcorgonization of Railroad Corporations Under Section 77 of the Bankruptey Act, 33 CoL L. REv. 571 (1933). For more recent appraisals see, Polatsels, The Wrets of the Old $\pi, 34$ CoRNeIL: L. Q. 532 (1949); Swaine, note 1 stpra.

45. Swaine, supra note 1 , at 1037.

46. E.g. cases discussed in text infro. 
The Chicago, Milwaukee, St. Paul \& Pacific ${ }^{47}$ plan substituted systemsecured bonds for the numerous old bond issues secured by divisional liens, ${ }^{48}$ Proposed new securities were: (1) $4 \%$ Firsts secured by a first system mortgage $;^{49}(2)$ income bonds in two series ( $A$ and $B$ ) secured by a second system mortgage $;^{50}$ (3) non-cumulative preferred stock; ${ }^{51}$ (4) no-par common. ${ }^{52}$ The allowable capitalization based on expected earnings fell below the aggregate face claims of bondholders. ${ }^{53}$ Since the plan contemplated preserving old face claims, part of the most-junior bondholders' claim was wiped out. No equity was left for shareholders.

Allocation of new securities to compensate senior divisionally-secured bonds posed a knotty problem. Each class sought large portions of the more desirable securitjes, basing its demand on special indenture provisions and the particular earnings potential of its securing assets. ${ }^{64}$ The ICC examined the earnings record of divisional assets securing the various issues. For example, the fixed charges of Milwaukee \& Northern Firsts had been earned three times; the earnings coverage of the eastern division bonds and Milwaukee \& Northern Consolidateds was only 1.16 and 1.2 respectively. In view of the greater likelihood of earnings to meet the former class' interest charges, fairness required allocation of system securities sufficient to compen-

47. Group of Institutional Investors v. Chicago, Milwaukee, St. Paul \& Pacific Railroad Co., 318 U.S. 523 (1943).

48. Id. at 529 .

49. The new First Mortgage would have a first lien on all properties of the debtor, subject only to the lien of equipment obligations. Issuance of $\$ 58,923,171$ principal amount of First Mlortgage bonds was contemplated. Id. at 531-2.

50. This General Mortgage would have a lien on all property of the debtor subject only to the lien of the First Mortgage and and equipment obligations. Interest on both Series $A$ and $B$ income bonds, secured by the General Mortgage, would be $41 / 2 \%$, contingent on earnings and cumulative up to $13 \% / 2 \%$. Series $A$ had priority to interest over Series $B$. Series $B$ bonds were convertible into common at any time at the rate of ten shares per $\$ 1000$ bond. Both series $A$ and $B$ were entitled to a sinking fund out of available net income with annual payments equal to $1 / 2$ of $1 \%$ or the aggregate principal. Issuance of $\$ 57,256,669$ in series $A$ and $\$ 51,422,111$ in Series B bonds was contemplated. 1 l. at 532 .

51. New preferred, called Series $A$, had a $5 \%$ dividend rate and voting rights. Although non-cumulative, no dividends were payable on common unless there liad been paid or set aside for payment on Series A, dividends at the rate of $5 \%$ annually for the three consecutive income periods immediately preceding. And Series A preferred was to participate with common to the extent of $\$ 1$ per share after common received $\$ 3.50$ per" share. $I d$. at 532,532 n. 5 .

52. Each share had one vote. Over 500,000 shares were reserved for conversion of Series $B$ General Mortgage Bonds. Ibid.

53. Allowable capitalization was $\$ 548,533,321$. Id. at 534 . Total debt was $\$ 627,000,000$. Id. at 529 .

54. E.g. see summary of arguments made by Terre Haute bondholders. Id. at 546 et seq.

55. Id. at 559 . 
sate Milwaukee \& Northern Firsts for surrendering a more valuable interest claim. As a result, $70 \%$ of the former class' claim was paid in $4 \%$ Firsts and the remainder in Class $\mathrm{A}$ Incomes. The securities bundle given the latter classes contained a smaller percentage of the choicer bonds; $40 \% 0$ of their claim was paid in Class B Incomes and preferred stock.50 And the same lien-earnings approach measured the claims of the remaining divisional bonds.

The eastern divisional bonds appealed to the Supreme Court. While they had obtained "only a face amount of inferior securities equal to the face amount of their claims," the eastern divisionals charged that more-junior 50year bonds had received a large amount of common stock. 57 The eastern divisionals also claimed credit for earnings of some eastern lines allegedly securing their mortgage. ${ }^{58}$ The ICC had not determined whether this property was subject to an "after-acquired" clause in the complaining bondholders' indenture; instead, the ICC simply had credited the earnings to the Adjustment bonds." The Court agreed with both contentions: "Where junior interests participate in a plan and where senior creditors are allotted only a face amount of inferior securities equal to the face amount of their claims, they 'must receive, in addition, compensation for the [surrendered] senior rights." "6o While the Supreme Court held the ICC's divisional analysis essential to allocation fairness, the absence of a finding on the coverage of the "after-acquired" clause was also reversible error:"1 whether senior creditors have been fully compensated "involves a consideration of the numerous investment features of the old and new securities and a financial analysis of many factors."62 Remanding, the Court directed the ICC and the district court to determine the coverage of the "after-acquired" clause and what the eastern divisionals should receive in addition to an equal face amount of inferior securities "as equitable compensation, qualitative or quantitative, for the loss of their senior rights."

The Denver \& Rio Grande Westcri $^{64}$ plan also demanded divisional analysis. New first mortgage bonds, income bonds, preferred and common stock replaced the numerous old bond classes. Claimants received varying

56. Id. at 534-5.

57. Id. at 569 .

58. Id. at 568 .

59. Ibid.

60. Ibid.

61. Id. at 568-9.

62. Id. at 571 .

63. Ibid.

64. Denver \& Rio Grande Western Railroad Company Reorganization, 254 I.C.C. 349 (1943), aff'd, In re Denver \& Rio Grande Western Railraad Company, 62 F.Supp. 384 (D. Colorado 1944), rev'd, 150 F2d 28 (10th Cir. 1945), resid sub nons. RFC v. Denver \& Rio Grande Western Railroad Company, 323 U.S. 495 (1946); noted in 60 HaRv. L. Rev. 291 (1946) ; 14 U. ChI. L. Rev. 84 (1946). 
proportions of these four new securities. ${ }^{65}$ The ICC estimated the relative contribution of each issue's underlying properties to system earnings. And the new bundles reflected each lien's contribution to the system's value: more valuable liens received larger proportions of the choicer securities. ${ }^{\text {60 }}$ Although only the ICC's decision on allowable capitalization-not securities allocationwas challenged by junior interests, the Supreme Court, in dicta, approved the Commission's lien-earnings analysis. ${ }^{67}$

The "qualitative or quantitative" compensation the Supreme Court had required in Chicago, Milwankee, St. Paul \& Pacific ${ }^{68}$ is illustrated by the Missouri Pacific ${ }^{60}$ reorganization. Missouri Pacific and two of its subsidiaries, International and New Orleans, entered reorganization. While insolvency struck the parent and International, New Orleans remained comparatively prosperous. ${ }^{70}$ Mindful of the public interest and "feasibility," the ICC insisted on merging the subsidiaries with the parent and issuing system

65.

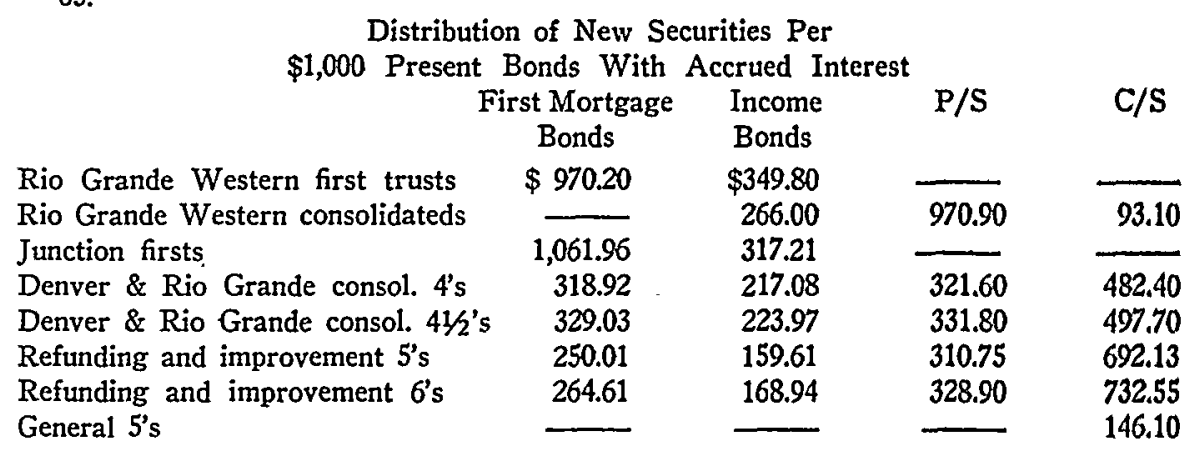

328 U.S. at 502 n. 6. All new securities had a par value. The plan eliminated shareholders, unsecured creditors and $90 \%$ of the most-junior bondholders' (General 5's) claims. Id. at 502 .

66. "The value of a lien on a part of a railroad when the valuation is made from earnings cannot be fixed solely on a mileage basis. Nor is it practicable to issue new securities with a lien limited to the property that was covered by the old lien. There must be segregation of the system earnings to each existing lien and allocation of sccuritics representing the system value to each class of claimants. This was done here as shown in the ... table... [note 65 supra]. Such a method is in full accord with the principle that senior creditors are to retain their relative priority of position in a reorganization." I $l$. at 517.

67. Id. at 534. See dicta quoted in note 66 sitpra.

68. See text at note 63 supra.

69. Missouri Pacific Railroad Reorganization, 275 I.C.C. 59, 203 (1949), approved, In re Missouri Pacific Railroad Company, 93 F. Supp. 832 (E.D. Mo. 1950), aff'd sub nom. State of Texas v. Group of Institutional Investors, 191 F.2d 265 (8th Cir. 1951). These reports represent the most recent stage of reorganization proceedings that commenced in 1933.

70. The Commission valued New Orleans at $\$ 83,700,000$. 191 F.2d at 273. Bondholders' claims, including Equipment Obligations, but excluding unsecured creditors, were less than $\$ 44,000,000$ as of January 1, 1948. 93 F.Supp. at 855 (Appendix D). 
securities. $^{71}$ As a consequence, treatment of prosperous New Orleans securities posed a major allocation problem.

The ICC examined the earnings potential of assets underlying the securities to measure the comparative worth of each class' income claim. The plan gave New Orleans' only bond issue its principal in Series A Firsts-choicest of the new system securities-and its unpaid interest in cash. No other security fared so well. ${ }^{72}$ New Orleans common (par $\$ 100$ ) had been valued at $\$ 150$ per share on the basis of that subsidiary's past and prospective earnings, ${ }^{73}$ so that public holders of the stock were allotted $\$ 150$ per share in new system income bonds. ${ }^{74}$ And to compensate for dilution of the right to share in New Orleans' earnings, each old share was entitled to $1 / 4$ share of new Class A common ( $\$ 100$ stated-value). ${ }^{75}$ Thus, total face value of the new securities given for each $\$ 100$ par value was $\$ 175$. The ICC accorded comparable treatment to Missouri Pacific serial bonds secured by parent-held New Orleans common; and the Eighth Circuit approved the plan. ${ }^{70}$

Since roads in reorganization in the past have rarely had assets exceeding the face amount of debt, generalization regarding treatment of preferred shares under $\$ 77$ is difficult. However, courts make no doctrinal distinction between Chapter $\mathrm{X}$ and $\$ 77$ reorganizations. Thus, despite the fact that liquidation is indeed a remote alternative to reorganization, Contral States' main reliance on preferred liquidation preferences may indicate the lead $\$ 77$ courts will follow. In cases where preferred has participated in $\$ 77$ reorganizations, their liquidation claims so far exceeded the value of remaining securities that other yardsticks probably would not have permitted juniors' participation either.77

71. 275 I.C.C. at $105-6 ; 191$ F.2d at 269-71.

72. Holders of equipment obligations and general claims, however, were given preference over all other claimants, including New Orleans bondholders. 275 I.C.C. at 131.

73. Id. at 125 .

74. Ibid.

75. Id. at 125-6. In effect, allocation of the relatively high-quality system bonds and the "extra" system common was a tribute to the high investment value of New Orleans common.

76. Since the stock (almost $82 \%$ of the total outstanding) pledged as collateral for the serial bonds represented the controlling interest in New Orleans, the ICC felt these shares "may ... have a greater value than the small amount of shares outstanding with the public although such additional value is speculative and not susceptible of appraisal. This control value entitles the holders of these [serial] bonds to a more favorable overall treatment in the reorganization in satisfaction of their total claim than if the amount of New Orleans stock held as collateral did not represent such control." Id. at 126.

77. Chicago and Eastern Illinois Railway Company Reorganization, 230 I.C.C. 199 (1938). Dollar value of remaining authorized capitalization was $\$ 10,401,783$; preferreds" liquidation claim (par plus arrearages) was $\$ 39,242,058$. "[T] $T$ he right of the preferred stockholders to receive cumulative dividends and the amount of these unpaid dividends ... must be considered in preference to the right of the holders of common stock to participate in the securities of the reorganized company." Id. at 231-2. In re Chicago, Greast Western Railway Company, 29 F.Supp. 149 (N.D. Ill. 1939) Par value of remaining authorized securities equaled \$11,518,400; preierrcds" liquidation elaim (inclu.1ing arrearages) was $\$ \$ 7,539,650$. Id. at 160 . See quotation in text at note 78 infro. 
In the Chicago, Great Western Railway case, for example, the district court rejected common's argument for participation, reasoning that "those [preferred] stockholders receive shares having a total par value of $\$ 11,518,400$. .. . This stock is given them for a total claim of $\$ 87,539,650$ including accumulated dividends. It is self-evident that this treatment does not fully compensate them."78 Similarly in Missouri Pacific new securities allotted to preferred shareholders fell so far short of their liquidation claim that little analysis was needed to substantiate the ICC's opinion that common had no value. ${ }^{79}$

Problems created by mergers and substitution of system securities for divisional-bonds demonstrate how in $\$ 77$ cases analysis of the full investment value measures debt claims which must be "fully" compensated. And the same analysis was applied to New Orleans common stock in Missouri Pacific. Face claims have only limited utility when the earning potentials of securing assets vary. The problem is the same-in more complex form-that Consolidated Rock Products presented. But $\$ 77$ cases make explicit what was perhaps implicit in that case under Chapter X. Even when total corporate worth exceeds the face claims of bond classes, investment value analysis of other aspects of their contract rights is essential to ensure fair allocations. Under $\S 77$, the courts look to the present value of a bond's claim to earnings, as well as to its other features. The greater the likelihood of divisional earn-

Missouri Pacific Railroad Company Reorganization, 275 I.C.C. 59 (1949), plan approved, In re Missouri Pacific Railroad Co., 93 F.Supp. 832 (E.D. Mo. 1950), aff'd sub nom. State of Texas v. Group of Institutional Investors, 191 F.2d 265 (8th Cir. 1951). Remaining authorized capitalization was about $\$ 30,000,000$; preferreds' claim, including accumulated dividends, exceeded $\$ 163,000,000$. 275 I.C.C. at 130.

78. In re Chicago, Great Western Railway Company, 29 F.Supp. 149, 160 (N.D. I11. 1939) (emphasis added).

79. 275 I.C.C. at 130 . See note 77 supra. But cf. the district court's reasoning in upholding the plan. "After satisfaction of creditors, only about $\$ 30,000,000$ par value Class B common stock of the new System securities remained. It is argued that it is improper to require satisfaction of the accumulated dividends on the preferred stock, before permitting common stockholders to share in the remaining equity. As the Commission said, under the circumstances there could be no other method of satisfaction of the preferred stock claim. The relative priorities could not otherwise be maintained except by a requirement that the first $\$ 92,000,000$ in dividends declared on this $\$ 30,000,000$ Class B stock be paid to the old preferred holders. Assuming an annual $\$ 5$ dividend, payment of $\$ 92,000,000$ would take about sixty years. It is impossible to find that the common stock has any equity." $93 \mathrm{~F}$. Supp. at 850-1. This analysis parallels investment value analysis of preferred and common stock claims under the Holding Company Act and $\$ \$ 5$ and $20 \mathrm{~b}$ of the Interstate Commerce Act, discussed in the text infra. However, in affirm* ing this treatment of preferred, the Eighth Circuit merely cited its approval without a discussion. $191 \mathrm{~F} .2 \mathrm{~d}$ at 265. 
ings to pay fixed-interest charges, the more valuable is that interest claim. The "quality" or "quantity" of new securities may furnish the "equitable equivalent" of old rights. More valuable claims may receive new securities with the same face value given other claimants, but the securities must be of higher quality. Or, superior old claims may receive larger face amounts of the same grade given juniors. In short, "full compensation" requires that reorganization plans recognize differing values.

\section{Investment Value In Holding Company Siamplifications}

As in Chapter X and $\S 77$ of the Bankruptcy Act, Congress made "fair and equitable" the substantive criterion for simplifications under $\$ 11$ of the Public Utility Holding Company Act of $1935 .{ }^{80}$ Section 11 requires registered holding companies to simplify their corporate structures where holding company units unnecessarily complicate the system, where voting power is inequitably distributed and where there are more than two levels of holding companies above the operating base. ${ }^{\text {sI }}$ To reach these goals, the SEC was empowered to amend and approve plans voluntarily submitted by holding companies, ${ }^{\mathbf{3 2}}$ or initiate proceedings where utilities offered no plans. ${ }^{83}$

The Commission interpreted "fair and equitable" against a significant factual backdrop. Holding companies' publicly-held preferred stock, at the end of 1938 , had involuntary liquidation claims topping $\$ 3,500,000,000 .^{\text {st }}$ Thus, allocation of new securities based on full recognition of old liquidation preferences often would have wiped out common stock interests. But management control stemmed from concentrated looldings of common, and wholesale obliteration of their interests would hardly have evoked cooperation from an industry already hostile to the Act's mandates. ${ }^{85}$ Furthermore, common holders, to avoid erasure of their interests, would undoubtedly have pressed the Commission to simplify by methods other than dissolution or liquidation ${ }^{80}$

S0. 49 STAT. $\$ 03,821$ (1935), 15 U.S.C. $\$ 79 \mathrm{~K}$ (1946). For comprehensive discussion of the Act's background, objectives, and operation, consult Comment, Scction 11(b) of The Holding Company Act: Fifteen Years In Retrospect, 59 Y YLE L.J. $108 S$ (1950). See also Blair-Smith \& Helfenstein, $A$ Death Sentence or a New Lcase on Life? A Strvey of Corporate Adjustments Under the Public Utility Holding Company Act, 94 U. of PA. L. Rev. 148 (1946); Dodd, The Relative Rights of Preferred and Common: Shareholders in Recapitalization Plans under the Holding Company Act, 57 HARv. L. REv. 295 (1944) ; Note, 93 U. of PA. L. Rev. 308 (1945).

81. §11(b) (2).

82. $\$ 11(\mathrm{e})$. Almost all holding company systems subject to the Act have taken advantage of this opportunity. Comment, supre note 80 , at 1107.

83. $\S 11(b)(2)$.

84. $56 \%$ of holding company preferred and $27 \%$ of preferred issued by operating companies had dividend arrearages. Dodd, sipra note 80 , at 303.

85. See Comment, supra note $\mathrm{S0}$, at 1111.

86. For illustrations of different simplification techniques, see Blair-Smith \& Helfenstein, supra note $\mathrm{SO}$, at $15 \%-8$. Cf. "[I]t should be immaterial whether the simplifieation 
United Light \&.Power Co. illustrates the SEC's investment value approach to measuring the relative claims of preferred and common shareholders. ${ }^{87}$ The simplification plan called for Power's dissolution and distribution of its portfolio securities. Power's preferred had a charter liquiclation claim of par $(\$ 100)$ plus dividend arrearages, before common could share in the assets, in the event of "dissolution or liquidation." Preferred's claim, including \$38, 700,000 in dividend arrearages, exceeded $\$ 98,700,000$. $^{88}$ Since the portfolio securities were valued at roughly $\$ 81,000,000,80$ common would receive nothing if preferred's liquidation rights alone measured its claim. But the SEC held a $\S 11$ simplification not a liquidation within the meaning of the charter; the charter-liquidation preference, therefore, did not control.00 Instead, the Commission attempted to value preferred and common's claim to future earnings. On the assumption that Power would continue in business, the SEC estimated future average annual earnings of $\$ 6,185,0000^{01}$ Since the annual preferred dividend requirements were $\$ 3,600,000$, a balance of $\$ 2,585$,000 would be available annually to pay off preferred's arrearages. Further postulating that all available income would, in fact, be used to pay current dividend requirements and reduce arrearages, the Commission found that common would share in Power's earnings after 15 years. ${ }^{22}$ The SEC then allotted common $5.48 \%$ of Power's portfolio securities. ${ }^{93}$

process takes the form of a recapitalization, merger, or distribution of the assets of a holding company in liquidation. In other words, the 'fair and equitable' standard requires the same recognition of substantive rights irrespective of the method employed in a particular case for attaining the objective of Section 11(b)(2)." United Light \& Power Co., SEC Holding Co. Act Release No. 4215, p. 10 (April 6, 1943). See note 97 infra.

87. SEC Holding Co. Act Release No. 4215 (April 6, 1943).

88. Id. at 6 .

89. This figure was the book value of Power's assets. On the basis of a capitalization of reasonably anticipated earnings, the SEC was "unable to find an over-all value for the assets which approaches $\$ 98,700,000 . "$ Id. at 7-8.

90. Id. at 34. "Decisions like . . L Los Angeles Lumber and Boyd . . . are predicated on sets of facts fundamentally distinguishable from the situation arising here. In bankruptcy or equity reorganizations, where some financial disaster overtakes ar threatens to overtake an enterprise, the courts and Congress have proceeded on the theory that it is often in the interest of creditors and other claimants that the enterprise be permitted to continue in operation, but with a new capital structure. Creditors and other claimants are prevented from foreclosing or otherwise compelling an actual liquidation, but new securities are distributed among them according to their contractual rights determined as though in liquidation." Id. at 9.

The Commission's holding is contrary to its dicta in an earlier $\$ 11$ case. Federal Watcr Service Corp., \& S.E.C. 893 (1941). There the SEC said that if the appropriate \& 11 plan called for liquidation, "fair and equitable" would yield the same result as if the company were a debtor in a bankruptcy reorganization proceeding. Id. at 910.

91. SEC Holding Co. Act Release No. 4215, p. 18 (April 6, 1943).

92. Ibid.

93. The Company's plan initially gave common $8.8 \%$ of the portfolio securities. The Commission lowered this to "approximately 5\%." Id. at 19. 
Preferred carried the appeal to the Supreme Court: Otis \& Co. v. SEC upheld the Commission. ${ }^{94}$ The majority held charter liquidation rights not exclusively binding: "absolute priority" embodied in the statutory "fair and equitable" standard did not require liquidation rights to be the sole basis for claims measurement. ${ }^{95}$ The Court reasoned that the applicability of the charter provision under the Holding Company Act was a matter of federal law. ${ }^{96}$ And Congress did not intend the operation of the Act to destroy legitimate investment values: "Enforcement of an overriding public policy should not have its effect visited on one class with a corresponding windfall to another class of security holders."' Fi Further, Congress did not intend the Act to mature otherwise dormant rights. ${ }^{93}$ The minority, on the other hand, started with the charter-fixed liquidation priority: since the plan required liquidation, liquidation rights should have controlled allocations to preferred. ${ }^{93}$ Moreover, the minority found it difficult to believe that a stockholder who contracted for liquidation priority was at all concerned with particular reasons for liquidation. ${ }^{100}$

While Otis ruled out liquidation rights as to the sole allocation guide, Central-Illinois ${ }^{101}$ defined the factors relevant to investment value analysis. Central-Illinois involved liquidation of the Engineers Public Service Company and distribution of proceeds to its common and three classes of preferred stock. All three classes had involuntary liquidation preferences of $\$ 100$ and call prices of $\$ 105, \$ 110$, and $\$ 110$ respectively. After considering issuance price as well as dividend and market history, the Commission analyzed assets and earnings coverage of each preferred class and found their investment value at least equal to the respective call prices. ${ }^{102}$ In reaching this conclusion, the SEC relied most heavily on expert testimony concerning estimated earnings, which when capitalized exceeded call price. ${ }^{103}$ However the district court, in light

94. 323 U.S. 624 (1945); noted, c.g., 58 HaRv. L. REv. 604 (1945).

95. 323 U.S. at $633-6$.

96. Id. at 636 .

97. "[C]ommon stock values... [should not] depend on whether the Commission, in enforcing compliance with the Act, resorts to dissolution of a particular company in the holding company system, or resorts instead to the devices of merger or consolidation which would not run afoul of a charter provision. ... The Commission in its enforeement of the policies of the Act should not be hampered in its determination of the proper type of holding company structure by considerations of avoidance of harsh effects on various stock interests. ..." Id. at 637-8.

98. Id. at 638 .

99. Id. at $643-4$.

100. Id. at 644 .

101. SEC v. Central-IIlinois Securities Corp., 338 U.S. 96 (1949). For full discussion see Dodd, Preferred Shareholders' Rights-The Engincers Public Scriec Company Case, 63 Harv. L. REv. 298 (1949).

102. 338 U.S. at $103,106,144-6$.

103. Id. at $104-5,144$. 
of "colloquial equities," amended the plan to reduce preferreds' claim to $\$ 100$ per share. ${ }^{104}$ The lower court felt "practically certain" that the company received no more than $\$ 98$ per share for any of the three classes and that the public had paid no more than $\$ 100$ per share. Thus the court held it unfair to allow preferred shareholders their call premium. ${ }^{105}$ The Supreme Court reversed.100 It upheld the Commission, brushing "colloquial equities" aside. For the Court, the only relevant factors were those affecting investment value; issuance price and market history were not determinative of investor claims. Since the Commission had not departed from "legal standards," and supported its finding with "substantial evidence," the district court erred. ${ }^{107}$

More recently, in the Leventritt case, ${ }^{108}$ the Supreme Court upheld the elimination of perpetual stock warrants despite a showing of present market value. Estimating the corporation's prospective earnings, the Commission discovered no reasonable expectation that the market price of the stock would exceed the option price in the foreseeable future. The Court deemed "the informed judgment of the Commission, rather than that of the market" the appropriate guide to "fair and equitable" under the Holding Company Act. ${ }^{109}$

Investment value analysis, however, does not guarantee common participation. If estimated earnings, absent simplification, cannot meet preferred dividend requirements, common is excluded. ${ }^{110}$ Similarly, common will be excluded if too many years would elapse before it could share in earnings. Although no automatic cut-off date exists, common has not participated in any plan where it had no earnings prospects for the next thirty-five years. ${ }^{111}$

104. 71 F. Supp. 797, 801 (D. Del. 1947).

105. Ibid.

106. SEC v. Central-Illinois Securities Corp., 338 U.S. 96 (1949). The Third Circuit had reversed the district court on the issue of the lower court's power to amend $\$ 11$ plans. 168 F.2d 722 (3d Cir. 1948). The Supreme Court reversed and remanded to the district court with directions to reinstate the Commission's judgment. 338 U.S. at 155 .

107. Id. at 151-2, 155.

108. Niagara Hudson Power Corp. v. Leventritt, 340 U.S. 336 (1951); noted, 60 YALE L. J. 371 (1951) ; 37 VA. L. REv. 452 (1951).

109. 340 U.S. at 346-7.

110. E.g. Southern Colorado Power Co., SEC Holding Co. Act Release No. 4501 (August 24, 1943). "The annual dividend requirement of $\$ 3$ per share on the Class $A$ stock aggregates $\$ 330,000$. There is no apparent possibility that the income of the company would ever reach this amount after paying interest and current preferred dividend requirements. Under these circumstances we think that no participation for the Class $B$ stock is justified. ..." Id. at 18. Accord: Federal Water Service Corp., 8 S.E.C. 893, 914 (1941) (Class B common with no reasonable possibility of ever receiving dividends is eliminated).

111. (1) Federal Water Service Corp., 8 S.E.C. 893 (1941). Majority estimated 11 years to pay off preferred's arrearages. Id. at 905 . Class A common was allotted $5 \%$ of the new common stock. Id. at 913. (2) Virginia Public Service Co., SEC Holding Co. Act Release No. 4618 (October 16, 1943). Estimated 10-15 years to pay arrearages, 
While in theory the investment measure remains the same whether old investors are paid in cash or new securities, the SEC's emplasis in fact shifts with the medium of payment. If old shareholders receive new securities, the Commission seeks to equate earnings expectations, risk factors, and liquidation privileges of the old and new securities; no dollar value is fixed for either. ${ }^{112}$ But if cash is distributed, dollar valuation of old securities becomes necessary. Here the SEC tests compensation against the cost of comparable securities enabling the investor to approximate his former investment position. As a consequence, heavy weight is given market value of these investment alternatives. ${ }^{113}$

In contrast to stocks, $\S 11$ measurement of bondholders' claims has presented few problems. Bondholders' clains to principal are usually paid in cash. ${ }^{114}$ And when the investment value-based on favorable maturity date, interest rate, and risk factors-exceeds the principal, a bond may receive up to its redemption price. ${ }^{115}$ In Community Gas $\&$ Power, ${ }^{116}$ however, the SEC allocated no-par common with average annual expected dividends of $\$ 75.58$ to debentures yielding $\$ 60$ annually. ${ }^{117}$ The Third Circuit did not question the Commission's view that the primary measure of debenture

id. at 29 ; common given $9 \%$ of new common, id. at 31. (3) Amerian Utilities Service Corp., SEC Holding Co. Act Release No. 5114 (June 22, 1944). Nine years to pay arrearages, id. at 10 ; common received about $15 \%$, id. at 12. (4) Puget Sound Power and Light Co., SEC Holding Co. Act Release No. 4255 (April 28, 1943). 18.4 to 34.1 years necessary to pay arrearages, depending on earnings estimate used, id. at 23; common received approximately $3 \%$ of the new common, id. at 26 . But if. Commissioner Healy's dissenting view on common's dividend prospects. Id. at 58. And see Southern Colorado Power Co., SEC Holding Co. Act Release No. 4501 (April 24, 1943). "While the existence of an accumulation of the preferred dividends of over $\$ 1,300,000$ would make it impossible for the Class $A$ stock to receive any dividends for a mumber of years, we [the SEC] think that there is sufficient pussibility that the Class A stack might some time receive some income from the company to warrant participation by the Class A stock ..."Id. at IS (emphasis added). Commissioner Healy in dissent, however, computed the future date of the stock's dividend prospects: 95 years distant. "When common stock cannot be expected to participate for so many years I do not believe it has a value" Id. at 36 . For Commissioner Healy's persistent dissents from the majority's investment value approach see Note, 93 U. of P.. L. REv. 308,317 n. 48 (1945).

112. SEC v. Central-Illinois Securities Corp., 338 U.S. 96, 143-4 (1949).

113. Id. at 144. But see Community Gas and Power Co., SEC Holding Co. Act Release No. 7131 (January 15, 1947). "Though market prices of comparable securities may be considered in arriving at price-earnings ratios, even those figures are for cumparison purposes only, and are not determinative." Id. at 20 .

114. 338 U.S. at 157 n. 4. Since these companies are solvent, there is no prublem of unpaid interest.

115. E.g. American Power and Light Co., SEC Holding Co. Act Release No. 6176 (November 1, 1945).

116. SEC Holding Co. Act Release No. 7131 (January 15, 1947), approect, In re Community Gas and Power Co., 71 F.Supp. 171 (D. Del. 1947), aff'd, 168 F.2d 740 (3d Cir.), cert. denied, 334 U.S. $\$ 46$ (1947) ; noted, 49 COL L. REv. 134 (1949).

117. SEC Holding Co. Act Release No. 7131, p. 16 (January 15, 1947). 
holders' rights was their claim to prospective earnings, not the bonds' face value or the market value of securities allocated. ${ }^{118}$ And the larger anticipated return fully compensated them for receipt of an inferior grade of securities.

Consideration of liquidation preferences as but one of the rights old investors relinquish has favored common stock interests. Clearly, investment value analysis has enabled common to participate when sole reliance on preferred liquidation claims would have excluded them. ${ }^{110}$ The SEC further enhances common's position by frequently relying on cheerful estimates of future earnings to determine if and how much common will share. ${ }^{120}$ In the United Light $\&$ Power dissolution, for example, future average annual earnings were estimated above $\$ 6,000,000$. But not only did this amount approximate the most optimistic estimate made; actual earnings had topped it only once in the prior decade. ${ }^{121}$ True, less optimistic estimates might grant preferred holders earnings above stock guarantees. ${ }^{122}$ However, when both preferred and common receive different quantities of the same securities, common gets a windfall in the event of income falling below estimated levels. Also running through SEC computations is the admittedly unrealistic assump. tion that all available future earnings will be applied to pay current preferred

118. Id. at 20. In re Community Gas and Power Co., 168 F.2d 740 (3d Cir.), ccrt. denied, 334 U.S. 846 (1947).

119. See cases cited in note 111 supra.

120. E.g. American Utilities Service Corp., SEC Holding Co. Act Relense No. 5114 (June 22, 1944). The Commission assumed net income applicable to preferred and common stocks to be $\$ 245,000$. Id. at 10 . In the period from 1938-1943 neither the average nor any one year's income reached this figure. Id. at 9; Federal Water Service Corp., 8 S.E.C. 893 (1941). Compare the 1935-1940 actual earnings with the 1941 cstimalcd earnings. The latter figure was apparently the basis for the Commission's decision. Id. at 905,932 .

"[T] he Commission's view is that common shareholders are entitled to participation even though they would, if the capital structure remained unchanged, participate in carnings only if the unfavorable possibilities did not eventuate and the actual future carnings approached more nearly to the maximum rather than to the minimum or even the median estimate which an informed foresight would have made." Dodd, supra note 80, at 317. See also $i d$. at 300 .

121. Management offered the most optimistic earnings estimate : between $\$ 6,500,000$ and $\$ 7,000,000$. "However, it must be pointed out that in view of the actual earnings experience and the intangible factors discussed, this figure must be regarded as a very liberal assumption as to earning power." United Light and Power Co., SEC Holding Co. Act Release No. 4215, pp.18-9 (April 6, 1943).

122. See Otis and Co. v. SEC, 323 U.S. 624 (1945). "Only by means of forced liquidation and the receipt of all ... [the common], could Power's preferred gain a right to prospective earnings above its guaranteed dividends." Id. at 632. "Enforcement of an overriding public policy should not have its effect visited on one class with a corresponding windfall to another class of security holders." Id. at 637. 
dividends and reduce arrearages. ${ }^{123}$ This hastens the date of common's earning participation, and thus supports present allocations to it. Moreover, while theoretically there is no minimum amount preferred must receive, call price sets a ceiling on its participation. ${ }^{124}$

\section{Investaient Value in Railroad Mergers Under $\$ 5$ of the Interstate CoMrarerce ACT}

Section 5 of the Interstate Commerce Act ${ }^{125}$ authorizes the ICC to amend and approve railroad merger or consolidation plans which are "just and reasonable" and in the "public interest."120 Power to initiate plans, however, rests solely with carrier management. Fostering "an integrated, efficient and coordinated system" of rail transportation via this Act ${ }^{12 \tau}$ thus depends largely on railroad cooperation.

The Supreme Court first interpreted "just and reasonable" in the Schwobacher case. ${ }^{128}$ The controversy arose out of the Chesapeake \& Ohio and Pere Marquette merger. ${ }^{129}$ Pere Marquette's charter provided that in case of a voluntary or involuntary "dissolution, liquidation, or winding up of the company," preferred would receive par ( $\$ 100)$ plus arrearages before common participation. Arrearages totaled $\$ 72.50$ per share when merger proceedings began in 1945. The ICC refused to require allocations based on liquidation rights. Instead, the Commission considered the stock's market value, past yield, as well as dividend prospects. ${ }^{130}$ However, market value was apparently the most significant

123. Federal Water Service Corp., 8 S.E.C. 893, 905 (1941); American Utilities Corp., SEC Holding Co. Act Release No. 5114, p. 10 (June 22, 1944); United Light and Power Co., SEC Holding Co. Act Release No. 4215, p. 18 (April 6, 1943).

124. SEC v. Central-Illinois Securities Corp., 338 U.S. 96, 145 (1949).

125. 24 Stat. 380 (1887), as amended, 41 Stat. $4 \$ 0$ (1920), 54 Stat. 905 (1940), 49 U.S.C. $\$ 5(1946)$.

126. $\$ 5$ (1) and (2) (b). A strict reading of the statute apparently limits "just and reasonable" to ICC amendments to merger or consolidation proposals. "If the Commission finds that, subject to such terms and conditions and such modifications as it shall find to be just and reasonable, the proposed transaction is within the scope of ... [the statute] and will be consistent with the public interest, it shall enter an order approving ... such transaction. . . " Cf. Section 20b's "just and reasonable" test, note 142 infro. However, the Supreme Court regarded "just and reasonable" as applicable to the whole plan. See discussion of Schwabacher in text.

127. Schwabacher v. United States, 334 U.S. 182 (1948). See Dectaratio:t of NAtional Transportation Policy, 54 Stat. 899 (1940), preceding 49 U.S.C. $\$ 1$ (1945). For a review of federal railroad legislation pertaining to merger, see LEONASD, RAILroAd Consolidation under the Transportation Act of 1920 (1946).

128. Schwabacher v. United States, 334 U.S. 182 (1948); noted, 97 U. of PA. L. REv. 130 (1948).

129. Pere Marquette Railway Company Merger, 267 I.C.C. 207 (1947).

130. Id. at 246 . 
measure. ${ }^{131}$ While the market value per preferred share ranged from $\$ 87$ to $\$ 99$, the merger terms substituted stocks which would have realized about $\$ 90$ and $\$ 111$ per share on the same dates. ${ }^{132}$ And of course Pere Marquette common participated in the merger.

The Supreme Court upheld the allocation ${ }^{133}$ over preferred's contention that liquidation rights controlled. To the Court, interpretation of the Act's "just and reasonable" standard was a matter of "federal law"; charter liquidation rights "as a matter of federal law" did not apply. ${ }^{184}$ The Court further noted that, rather than the charter's promise to the stockholder, the "current worth of that promise" measured stockholders' claims. ${ }^{135}$ And, in dicta, the Court went beyond the immediate problem of shareholder rights. The purpose of the statute "to bring within its scope everything pertaining to the capital structures of such mergers could hardly be made more plain."180 Although the Chesapeake \& Ohio assumed without alterations all debts of Pere Marquette, the dictum implies that bonds as well as stocks may be subject to ICC investment value analysis. The Court relied heavily on Otis, a case under "a federal statute of very similar purposes."137 "Fair and equitable" and "just and reasonable" thus coalesced.

Like Otis under $\$ 11$, Schwabacher adapts allocation standards to $\S 5$ 's statutory goals. Roads whose low earnings have left preferred or income bond arrearages may need the efficiencies flowing from unified operations. Yet management, representing common stock interests, will not seek merger's or consolidations if preferreds' liquidation rights control allocations. Attenuation of liquidation rights thus implements $\S 5$ 's philosophy of transportation efficiency.

Investment Value Under $§ 20 \mathrm{~b}$ of the Interstate Commerce Act

Dissatisfaction with erasure of junior interests in lengthy and expensive $\S 77$ reorganizations inspired the Railroad Modification Law of 1948-section

131. "The controlling factor in the determination of the offer to the Pere Marquette was recent market prices for the stocks of the carriers affected." Id. at 235. But the ICC later added: "In the discharge of our duty ... to find whether the [merger] terms ... are just and reasonable, we cannot confine our inquiry to market opinion, but must give consideration to all relevant elements of value." Id. at 238.

132. Id. at $237-8$.

133. Schwabacher v. United States, 334 U.S. 182 (1948). However, the Court reversed the lower tribunals on the issue of whether dissenting shareholders have a right to pursue alternative remedies under state law. Id. at 200-2. On remand, the Commission reaffirmed the plan. 271 I.C.C. 667 (1949).

134. 334 U.S. at 198-9.

135. Id. at 199.

136. Id. at 198 (emphasis added).

137. Id. at 199. 
$20 \mathrm{~b}$ of the Interstate Commerce Act. ${ }^{138}$ Section $20 \mathrm{~b}$ seeks to facilitate future financing, and obviate the threat of $\$ 77$ bankruptcy reorganizations. ${ }^{150}$ Congress established a simple non-judicial procedure for reaching these goals: permission of the ICC and approval of $75 \%$ of each class of affected security holders make a modification plan binding on all security holders. ${ }^{140}$ ICC approval is contingent on its finding the plan in the "best interests" of each class of affected bondholders and each class of stockholders, as well as "just and reasonable."111 The "best interests" test apparently requires that each class of stockholders and affected bondholders bculfit by the plan; "just and reasonable," is the guide for securities allocations.112 And using investment value analysis, the ICC has shaped this allocation standard to $\$ 20 \mathrm{~b}$ procedures and goals.

Lehigh Valley was the first plan under $\$ 20 \mathrm{~b} .^{143}$ The road's capital structure largely consisted of seven bond classes and 1,200,000 shares of common stock ( $p a r \$ 50$ ). $\$ 32,500,000$ of bonded debt was due to mature within five years of the plan's filing, and an additional $\$ 12,500,000$ in the succeeding five years. Moreover, in eleven of the past twenty years the road had failed to earn fixed charges; and funds available for debt retirement were patently inadequate. The proposed plan extended impending maturities of five senior bond issues and set up sinking funds for their retirement. WWhile the maturity date of the seventh issue ("general") was distant, the bulk of the road's fixed

138. 62 STAт. 163 (1948), 49 U.S.C. $\$ 20 \mathrm{~b}$ (Supp. 1951). For full discussions of $20 \mathrm{~b}$ 's background and procedures consult: Hand \& Cummings, Comsensual Sceuritics Modification, 63 HARv. L. Rev. 957 (1950) ; Comment, Strcamlined Capilal Readjustment under Section $20 \mathrm{~b}$ of the Interstate Commerce Act, 58 YALE L. J. 1291, (1949); Note, Railrood Modification Act 1948, 1 STAN. L. REv. 676 (1949); Hand \& Cummings, The Railroad Modification Law', 48 CoL. L. Rev. $6 S 9$ (1948); Oliver, The Railread Adjustmen' Act, 15 I.C.C. Prac J. 527 (1948). See also, Blum, Inzestment Value Standard Under Railroad Miodification Act, 45 ILL. L. Rev. 357 (1950).

The ICC was among 20b's strongest backers. See ICC, Sixtietr Awruas Reross 24-7 (1946).

139. See Congriessional Declaration of Purpose of Act, following 49 U.S.C. $\$ 20 \mathrm{~b}$ (13) (Supp. 1951).

140. $\$ 20 \mathrm{~b}(2)$.

141. The ICC must also find that the proposed modifications will be "in the public interest," within the scope of the statute and "will not be adverse to the interest of any creditor of the carrier" not affected by such modifications. Ibid. See Sakis v. United States, Civil Action No. 763-51, D.D.C. p. 9, February 21, 1952.

142. The statutory wording of "just and reasonable" parallels §5. See note 126 supra. However, the ICC has interpreted the phrase as applying to more than just the "terms and conditions" it attaches to $\S 20 \mathrm{~b}$ applications; the whole modification plan must pass the test. For discussion of "best interests" and "just and reasonable" see Hand \& Cummings, Conssensual Securities Mrodification, 63 HaRv. L. REv. 957, 968-74 (1950); Hand \& Cummings, Funding Arrearages Under Section $20 b$ of the Interstate Commerec Act, 65 Hanv. L. Rev. 398, 402-16 (1952).

143. Lehigh Valley Railroad Co. Securities Modification, 271 I.C.C. 553 (1949); discussed in Hand \& Cummings, Consensual Securities Modification, 63 Hasv. L. Rev. 957, 959-61 (1950). 
charges resulted from these bonds. To lighten the burden of fixed charges, the plan made three-fourths of "general's" interest contingent on earnings, cumulative to three years. "General's" interest was payable only after the senior classes' interest and sinking fund requirements were met. The plan compensated "general" bondholders by giving them 4 shares of new no-par common for each $\$ 1,000$ bond. Old common was left with four fifths both of voting control and the right to dividends-subject to debt retirement and "general's" interest accumulations.

The "general" bondholders objected to the plan, contending that, while common was participating, the proposed modifications failed to compensate them fully for surrendered rights. ${ }^{144}$ In the Commission's view the plan was to be considered "from the standpoint of the interests of the various classes in a going business, with due regard, among other things, to their contract rights and earnings possibilities." 145 Citing Otis, the ICC noted that $\$ 20 \mathrm{~b}$ standards of compensation for surrendered rights "may differ" from those "in a proceeding contemplating a liquidation of the carrier's property."140 However, the ICC did amend the plan in "general's" favor: the cumulative interest period was extended from three to five years and the mortgage trustee was given the power to elect $1 / 3$ of the directors if four years' interest accumulated. With these amendments, the ICC found "general" bondholders "fully compensated for the rights surrendered." 147

In Lehigh Valley, as in ensuing $\S 20 \mathrm{~b}$ cases, the ICC has measured allocation fairness by weighing old against proposed income claims. ${ }^{148}$ Junior bondholders often make the greatest sacrifices through plans rendering fixedinterest claims contingent. ${ }^{149}$ Allocation of stocks, creation of sinking funds, and dividend restrictions are typical compensatory features. ${ }^{160}$ The lien analysis characteristic of $\$ 77$ reorganization is rare; only one plan, Maryland \&. Pennsylvania, ${ }^{151}$ altered the securing assets of bond classes. There, with the value of assets which secured competing bond claims in issue, the ICC without substantiating analysis of the $\$ 77$ type found the liens of equal value. ${ }^{152}$ Moreover, in at least one modification, New Jersey Central, junior bondholders admittedly received less than full compensation..$^{163}$ But since this

144. 271 I.C.C. at 579.

145. Id. at 590 .

146. Id. at 591 (emphasis added).

147. Id. at 595 (emphasis added).

148. E.g. Southern Railway Abandonment, 271 I.C.C. 605, 641 (1949) ; Maryland \& Pennsylvania Railroad Co. Securities Modification, 275 I.C.C. 695 , 712-13 (1950).

149. Lehigh Valley Railroad Co. Securities Modification, 271 I.C.C. 553 (1949); Maryland \& Pennsylvania Railroad Co. Securities Modification, 275 I.C.C. 695 (1950).

150. Southern Railway Co: Abandonment, 271 I.C.C. 605 (1949) illustrates the use of all three techniques.

151. 275 I.C.C. 695 (1949).

152. Id. at $713,716$.

153. Central Railroad Co. of New Jersey Securities Modification, 271 I.C.C. 501, 523

(1949). Cf. Southern Railway Co. Abandonment, 271 I.C.C. 605 (1949). 
road was already in a $\$ 77$ reorganization proceeding, the ICC thought the bondholders would benefit by a termination of that proceeding. ${ }^{154}$ MIoreover, feasibility required common's participation: the controlling interest was owned by the Reading Company-principal source of the road's traffic.15i Further comparisons with probable $\S 77$ results on similar facts are hard because $\$ 20 \mathrm{~b}$ applicants, except in one case, have not valued the road's assets on a capitalized earnings basis. 156

Maine Central ${ }^{157}$ was the first of two $\$ 20 \mathrm{~b}$ plans dealing exclusively with stock adjustments. The road's capital stock structure included three stock classes: prior preference, preferred and common. Preferred's dividend rate was $5 \%$ and its liquidation preference was par $(\$ 100)$ plus arrearages. Since it had received no dividends since 1931 , arrearages totaled $\$ 85$ per share. However, operating revenues had increased almost steadily, and 1948 earnings amounted to $2 \mathrm{I} / 2$ times 1938 revenues. Noreover, the road had a substantial surplus when the petition was filed. The plan aimed to make recent and future earnings available for common dividends by eliminating preferred arrearages, raising preferred's par from $\$ 100$ to $\$ 185$. Further, the dividend rate was to be diminished from $5 \%$ to $4 \%$. As a result of these changes all stocks would be on a current dividend basis. According to the road, this streamlining would improve the carrier's credit position, and thereby facilitate future financing. ${ }^{158}$

Preferred holders objected and the ICC disapproved the plan. ${ }^{150}$ The road employed investment value analysis to demonstrate that, even on its estimate of future earnings, preferred would actually benefit from the plan: the right to receive $4 \%$ on $\$ 185$ in perpetuum was deemed more valuable than the rights to $5 \%$ on $\$ 100$ plus payment of the $\$ 85$ arrearages. ${ }^{100}$ And if preferred's more optimistic earnings estimate were accepted. preferred's benefit would be all the greater..$^{161}$ The seductive appeal of this analysis convinced neither preferred holders nor the ICC. ${ }^{102}$ The Commission found that there would probably be sufficient earnings to pay current preferred dividends and to

154. 271 I.C.C. at 524.

155. Id. at 513, 517. The plan would allow the road the "continued benefit from traffic relation with its affiliate" Id. at 524 .

156. The exception is Boston and MIaine Railroad Securities Modification, 275 I.C.C. 397 (1950).

157. Miaine Central Railroad Co. Securities Modification, 275 I.C.C. 2001 (1950). The plan is discussed in Hand \& Cummings, Funding Arrcarages Under Scetion $20 \mathrm{~b}$ of the Interstate Commerce Act, 65 HARv. L. REv. 398 (1952).

158. 275 I.C.C. at 266-7.

159. Perhaps a significant reason for the ICC's action was the opposition of a preferred stackholders' protective committee representing about $50 \%$ of the outstanding issue. Ibid. At the time of the ICC hearing, the rad's directors owned $\$ 0.15 \%$ of oustanding common. Id. at 288 .

160. Id. at 273 .

161. Id. at 273-4.

162. See note 159 supra. 
apply annually $\$ 2.40$ per share to pay off arrearages. At this rate, arrearages would be paid off in 31 years. Thus, the Commission concluded, there was no necessity for a plan which sacrificed preferred's priority to $\$ 85$ in arrear"* ages, but contemplated no sacrifices by common. As a restlt, the plan was held not in the "best interests" of preferred. ${ }^{163}$

Despite its disapproval on "best interests" grounds, the ICC sanctioned the road's use of investment value analysis to measure preferred's claim. The Commission noted that preferred holders under $\$ 20 \mathrm{~b}$ were entitled only to the equivalent of the present investment value of their contract on a going concern basis. ${ }^{16-4}$ In computing that value, past yields, market value, and future income prospects were all relevant factors. ${ }^{165}$ Therefore, in the present case, preferred had no right to receive money or property worth $\$ 85$ to compensate for surrender of the arrearage claim. ${ }^{160}$

Investment analysis of shareholders' claims fully blossomed in the Boston \& Maine plan. ${ }^{167}$ That road applied under $\$ 20 \mathrm{~b}$ to simplify its complicated capital structure, and thus improve marketability of its securities. The stock structure consisted of: (1) cumulative prior preference preferred; (2) five series of cumulative first preferred; (3) non-cumulative preferred; and (4) common. The liquidation preference of the two senior stocks was par $(\$ 100)$ plus arrearages. And arrearages had already mounted to $\$ 119$ per prior preference share and from $\$ 86.25$ to $\$ 172.50$ per share of the five series of first preferred. The plan contemplated two new stocks: cumulative-when-earned preferred and common, both at $\$ 100$ par. The total par of the proposed stock would be $\$ 22$ million less than the old. Valuation of the road based on capitalized future earnings required the reduction.

The petitioning road computed the number of years which would have been necessary under the old capital structure to pay off arrearages and place all the stocks on a current dividend basis. The computation assumed that all available estimated income, $\$ 4,370,831$, would be used to meet current dividend requirements and pay off arrearages. On the basis of these assumptions, the road estimated that 17 years would be required to pay off prior preferred's arrearages. This arrearage claim, discounted to present worth, was valued

163. 275 I.C.C. at 283. The Commission seems to have used "just and reasonable" language despite the "best interest" label.

164. Id. at 271-2.

165. The Commission, however, felt little weight could be given past yields and present market values in this case, "since the former have been controlled by the common-stock holders through ... [the road's] board of directors and the latter are based on the judgment of the market as to the probability of the ... proposal being approved." Id. at 281.

166. Id. at 272 .

167. Boston and Maine Railroad Securities Modification, 275 I.C.C. 397 (1950), aff'd, Sakis v. United States, Civil Action No. 763-51, D.D.C., February 21, 1952. The district court opinion is paraphrased in 20 U.S.L. WEEK 2389 (March 4, 1952). The plan is discussed in Hand \& Cummings, Funding Arrearages Under Section 206 of the Interstate Commerce $A c t, 65$ HaRv. L. Rev. 398 (1952). 
at $\$ 78.91$. Further, the road computed the investment value of prior preferred's principal claim of $7 \%$ on $\$ 100$. The road considered $\$ 100$ invested at $7 \%$ equal in value to $\$ 140$ at $5 \%$ (new preferred's dividend rate). But the ceiling on newly authorized preferred permitted each prior preference share to receive only $\$ 120$ in new preferred. The balance of prior preferred's principal claim- $5 \%$ of 20 -was paid in new common. As a result, one new share of common (par \$100) was issued to each prior preference share to cover both the remaining principal claim and the arrearage claim of $\$ 78.91 .{ }^{165}$ Although par value of 1.2 shares of new preferred and 1 share of new common equaled par value of the prior preference, the old shareholders' earnings priority was reduced $\$ 1$ per share.

The road then attempted to use the investment value approach to measure first-preferred's claim. But here the plan hit a snag. Allotments to first preferred on the basis of investment value would have consumed all remaining authorized common, thereby eliminating both junior stocks. ${ }^{160}$ With no dividend prospects for at least 74 years, the road admitted that junior stocl: claims "defy value analysis."170 But on an "arbitrary judgment basis" the road allotted small portions of new common to the non-cumulative preferred and common. ${ }^{171}$ The need for such allocation was obvious: junior shareholders "could not be expected to vote themselves out of existence."172 The ICC amended the plan by slightly altering allocation among the different series of first-preferred. Emphasis on relative market values produced the change. ${ }^{173}$ The ICC then upheld all the allocations as "just and reasonable." In fact, by reasoning that the road contemplated ultimate payment of all arrearages and retirement of debt, the Commission found that the two junior stocks had a "legitimate, though small, investment value." To hold otherwise would "give undue weight" to liquidation rights. ${ }^{174}$ It then cited Otis.

In Sakis $v$. United States, ${ }^{175}$ first-preferred holders challenged the fairness of the Boston $\&$ Maine plan as well as $\$ 20 \mathrm{~b}$ 's constitutionality. Relying on Otis and Central-Illinois, a three-judge district court upheld the ICC's investment value approach to claims measurement. Specifically, the court sanctioned reliance on claims to future earnings as the prime measure of the investment contract's value. Since there was sufficient evidence in the record to support the Commission's finding that the plan was in the "best interests" of affected security holders and "just and reasonable," the court upheld the modification plan. Also rejected was plaintiff's claims that $\S 20 \mathrm{~b}$ violated due process by

168. The road's elaborate analysis is spelled out in the opinion. 275 I.C.C. at 426 n. 25.

169. Id. at 450 .

170. Id. at 428 .

171. Ibid.

172. Id. at 429 .

173. Id. at 450 .

174. Ibid.

175. Civil Action No. 763-51, D.D.C., February 21, 1952. The opinion is paraphrased in 20 U.S.L. WeEk 2389 (March 4, 1952). 
permitting $75 \%$ of a class of security holders to deprive the remaining $25 \%$ of their contract rights. The court reasoned that: "If contract rights stand in the way of the exercise by Congress of a power within its competence under the Constitution, the contract right must fall,"176 and held $\S 20 \mathrm{~b}$ a legitimate exercise of Congress' power to regulate railroad transportation. The contract alterations on the basis of present values were not deemed a capricious exercise of delegated power. ${ }^{177}$

In tailoring securities allocation to meet $\$ 20 \mathrm{~b}$ procedural and policy requirements, the ICC has relied heavily on the flexibility of investment value anlysis. In Boston \& Maine, for example, the Commission cited the junior shareholders' loss of voting rights to justify their participation ${ }^{\mathbf{1 7 8}}$ - despite the fact that they had no reasonable dividend expectations for the next 74 years. In effect, the ICC seconded the road's admission that junior shareholders' power to block modification must be rewarded. The consensual nature of $\$ 20 \mathrm{~b}$ modifications probably demands this cleparture from standards of other reorganization statutes. New Jersey Central produced another $\$ 20 \mathrm{~b}$ innovationpermitting junior interests to participate although seniors admittedly were not fully compensated. Not only $\S 20 \mathrm{~b}$ procedure but feasibility required this result: the road's principal customer owned the bulk of common. While Sakis upheld the validity of investment value alterations of stock contracts, the constitutionality of a New Jersey Central type of $\$ 20 \mathrm{~b}$ plan, allowing junior participation when senior interests are not fully compensated, is yet to be ruled on by the courts.

\section{. Evaluaton and Conclusion}

In all reorganization contexts bondholder claims are measured alike. Since earnings potential is the primary gauge of economic worth, investment value analysis of bonds stresses the worth of old income rights to guide allocation of new securities. Community Light \& Power under the Holding Company Act is probably the best example: the plan's allotment of no-par common to debenture holders was justified because the stocks' prospective yield fully compensated them for relinquishing their fixed interest claim.

When competing bond classes are secured by separate assets, the earnings potential of these underlying assets is analyzed to value surrendered income claims. True, divisional-earnings examination may merely value securing assets to measure a bond's intrinsic worth ; but courts, preoccupied with earnings coverage, apparently seek to measure the relative value of competing income claims. This phase of investment value analysis of bond contracts is

176. Civil Action No. 763-51, D.D.C., p. 28.

177. Id. at 29 .

178. 275 I.C.C. at $428-9$. 
illustrated by Chicgo, Milwaukce, St. Paul \& Pacific's insistence on divisional earnings to determine allocation and Missouri Pacific's compensation of a prosperous subsidiary's bonds.

But investment value analysis supplements rather than supplants face amounts as a measure of bondholder claims. Theoretically, a $\$ 500$ bond bearing $15 \%$ with a 1995 maturity date would of course more than compensate a $\$ 1,000$ bond bearing $2 \%$ with the same maturity date. But high fixed charges are the nemesis of corporations with fluctuating incomes; railroads are the classic example. In the interests of "feasibility," therefore, reorganizers do not raise interest rates. ${ }^{179}$ Instead, they preserve face claims, including accrued interest and principal, whether matured, naturally or by an acceleration clause, or with distant maturity date. But investment value analysis goes beyond this face claim to measure the other contract rights surrendered. Of these, earnings rights are most important. And within limits set by "feasibility," compensation for more valuable rights is made in either choicer new securities of the same face value or a larger quantity of securities with an inferior income claim, or both. This investment value analysis in fact is the "bundle of rights" approach of Chicago, Milwaukee, St. Paul \& Pacific.

In contrast to uniformly applied bond measurement criteria, yardsticls for measurement of stockholder claims vary with reorganization settings. To measure "the claim" of preferred holders, in Chapter X and perhaps $\$ 77$ proceedings as well, lower courts consider preferred stock liquidation claims matured, directly analogous to Los Angcles Lumber's maturation of bondholders' principal. But under the Holding Company Act and $\$ \$ 5$ and $20 \mathrm{~b}$ of the Interstate Commerce Act, measurement of preferred shareholders' claims markedly differs. In these procedures the key to "the claim" that must be "fully compensated" is a current estimate of preferreds' claim to prospective carnings; "unmatured" liquidation rights are only one factor in the computations, and a minor one at that. Clearly, this investment value analysis of preferreds" claims has permitted junior participation when a valuation of the claim dominated preferred liquidation rights would have wiped them out. Unique pressures, policies, and procedures have nurtured the development of this analysis.

However, neither branding the yardstick "expedient" nor the contention that preferred shareholders would receive more under a "liquidation" standard resolves the basic problem: Which gauge corresponds more with the realities of corporate reorganizations and Boyd's cannon of "full compensation?" Liquidation is rarely a practical alternative to reorganization. Certainly, railroads and public utilities cannot liquidate; the specialized nature of their fixed assets and the public interest demands their continued operation. And

179. One $\$ 20 \mathrm{~b}$ plan furnishes a rare exception to this practice: the interest rate on one bond class was raised from $4 \%$ to $4 \% / 2 \%$, thereby increasing fixed charges by about $\$ 25,000$ jearly. Bangor \& Aroostook Railroad Co. Securities Modification, 275 I.C.C. 369 (1950). 
buyers with sufficient capital are unwilling to purchase decrepit roads outright. Similarly, other mass corporations whose going concern value exceeds liquidation value will reorganize. ${ }^{180}$ Thus, not only are liquidation rights literally inapplicable but reorganization is not a functional equivalent to liquidation invoking primary reliance on liquidation rights. ${ }^{181}$ In practice, "absolute priority" could not mark face or liquidation claims the sole or even primary measure of "the claim" that must be "fully compensated." Obviously, a 7\% non-cumulative preferred share with a $\$ 100$ liquidation claim is worth more than $5 \%$ preferred with equivalent features. Valuing all rights in the contract, rather than focusing on the liquidation right, directly implements Boyd's policy of "full compensation" for surrendered rights.

Investment value analysis should apply to stocks and bonds with equal force. Cases under the Holding Company Act and $\$ \S 5$ and $20 \mathrm{~b}$ of the Interstate Commerce Act illustrate how investment value analysis might be applied to stocks in Chapter $X$ and $\S 77$ reorganizations. Investment value analysis of this type could be as easily applied to bonds. For example, the claim of a $5 \%$ perpetual income bond with a liquidation right to $\$ 100$ plus arrearages can be measured identically with a preferred shareholder's analogous claim. ${ }^{184}$ Paralleling the treatment of preferreds' liquidation rights under the Holding Company Act, reorganization should not mature non-accelerated bond principal; the bond's right to a fixed sum at some future date, however, should enhance the value of the bondholder's claim. ${ }^{183}$ Since the average security holder in a mass capital corporation regards himself as an investor-not a creditor or aliquot owner-consistent investment value analysis probably accords with investor expectations.

Statutory allocation standards, moreover, do not impede expansion of investment value analysis. Simplifications under the Holding Company Act are governed by "fair and equitable"; but expediting the holding company overhaul required a departure from practices apparently prevailing under "fair and equitable" in Chapter $X$ and $\$ 77$. Claims measurement under the consensual procedures of $\$ \S 5$ and $20 \mathrm{~b}$ of the Interstate Commerce Act, though nominally governed by a "just and reasonable" standard, parallel the Holding Company Act approach. In short, claims measurement and resultant alloca-

180. See First National Bank of Cincinnati v. Flershem, 290 U.S. 504 (1934).

181. For a recent exposition of this view see Billyou, supra note 32 .

182. For an illustration of fully compensatory treatment of perpetual bonds under $\S 20 \mathrm{~b}$, see Lehigh Valley Railroad Co. Securities Modification, 271 I.C.C. 553 (1949). Perpetual $6 \%$ consolidated bonds were given a maturity date and made redeemable; to compensate for possible loss of the choice $6 \%$ interest rate the redemption price was set at $\$ 120$.

183. The maturity dates of competing bond classes will also affect apportionments between them. To illustrate: Reorganization in an expanding economy when investment alternatives are yielding $6 \%$ means that a matured $\$ 1,000$ bond bearing $4 \%$ is moro valuable than an unmatured $\$ 1,000$ bond bearing $4 \%$ with a maturity date 10 ycars distant. Conversely, in depression years, the unmatured bond may be more valuable. 
tions are moulded by specific reorganization contexts: the verbal standard"fair and equitable" or "just and reasonable"-does not itself define factual criteria. ${ }^{184}$

While investment value analysis theoretically harmonizes with "full compensation," its inherent flexibility may frustrate "absolute priority." The generalities of investment value analysis necessitate broad discretionary powers. Since courts accord great weight to the "informed discretion" of the SEC and ICC, judicial seconding of their approved plans is virtually guaranteed. ${ }^{185}$ The Boston \& Maine case is a perfect example of "stretched" investment value findings to ensure court approval. While the SEC may sometimes have been over-generous to common stockholders under the Holding Company Act, ${ }^{186}$ the Act's non-consensual procedures probably would have resulted in SEC erasure of the two Boston \& Maine junior stocks. Boston \& Maine, in effect, rewarded the junior shareholders for their nuisance value, in sharp contrast to Los Angeles Lumber's specific repudiation of nuisance value as a basis for shareholder participation in Chapter X reorganizations. ${ }^{18 t}$ The $N_{\mathrm{eat}}$ Jersey Central type of plan, where juniors participate though seniors were admittedly not fully compensated, is a further consequence of a wholly consensual procedure. ${ }^{188}$ Thus, cheap and rapid reorganization procedures of the $\S 20 \mathrm{~b}$ type may necessarily sacrifice fully compensatory treatment for senior claimants. In fact, $\S 20 \mathrm{~b}$ plans may revert to the products of loose "equity" receiverships" in pre- $\$ 77$ days, with the ICC in the role of the "friendly receiver." Investment value, in sum, can foster or frustrate Boyd's canon of full compensation for surrendered rights and junior exclusion when seniors are not fully compensated; agency discretion and reorganization procedures will decide.

184. For a discussion of the pervasive influence of Boyd, see Rostow \& Cutler, sigra note 2 , at $1346-52$.

185. See SEC v. Central-Illinois Securities Corp., 338 U.S. 96, 115-27 (1949); Niagara Hudson Power Corp. v. Leventritt, 340 U.S. 336, 346-7 (1951); Salis v. United States, Civil Action No. 763-51, D.D.C., February 21, 1952, p3raphrased in 20 U.S.L. WEEK 2389 (March 4, 1952). Illustrative of the consequences of failure to make proper "findings" is the Chicago, Milic'aukee. St. Paul \& Pacific plan: the Supreme Court reversed. See text at pp. 664-5 sipra.

For recent criticism of the manner in which the ICC has exercised discretionary powers in other areas of railroad interest, see Huntington, The Marasmus Of The ICC: The Commission, The Railroads, And The Public Interest, 61 YALE L. J. 467 (1952).

186. See notes 120 and 123 supra and text.

187. See note 20 supra.

188. True, dividend restrictions barred diversion of income from bondholders to shareholders; but the plan left old common holders with voting control although they had no equity left in the business.

Appropriate amendment of $\S 20 \mathrm{~b}$ could avoid such plans and yet foster capital readjustments without $\$ 77$ reorganizations. For example, once a ro3d petitions for modification under $\$ 20 \mathrm{~b}$, its withdrawal without ICC consent could be barred. And if a security is found to be valueless, its holders could be deprived of voting rights in plan approval. 